Implementing Assessment in an Outcome-Based Marketing Curriculum

\author{
Norm Borin
}

Orfalea College of Business, Cal Poly State University

San Luis Obispo, CA 93407

(805) 756-1762 (office)

(805) 756-6347 (fax)

nborin@calpoly.edu

Lynn E. Metcalf

Orfalea College of Business, Cal Poly State University

San Luis Obispo, CA 93407

(805) 756-2010 (office)

(805) 756-6347 (fax)

lmetcalf@calpoly.edu

\author{
Brian C. Tietje \\ Orfalea College of Business, Cal Poly State University \\ San Luis Obispo, CA 93407 \\ (805) 756-1757 (office) \\ (805) 756-6347 (fax) \\ btietje@calpoly.edu
}

Keywords: educator, assessment, college \& university, curriculum, marketing, outcome-based curriculum 


\title{
Implementing Assessment in an Outcome-Based Marketing Curriculum
}

\begin{abstract}
This article describes the development and implementation of assessment in our new outcomebased marketing curriculum (described fully in Borin, Metcalf, and Tietje 2007). Outcomes for the marketing curriculum were specified at the program, department, course, and lesson levels. Direct embedded assessments as well as indirect assessment methods were used to gauge student achievement. Results indicate that, on both self-reported (indirect) and direct, as well as nonembedded and embedded assessments, significant value-added learning occurred. We chronicle the stages in developing and implementing an assessment plan, and reflect on our experiences in the process to provide a roadmap for other marketing departments who also face the transition from teaching to learning.
\end{abstract}


Introduction

Assessing student learning in college has been on the national agenda since 1990 (Banta 2006). Pressures to develop a national assessment test abated in the mid 1990s but mounted once again in late 2005 when the Bush administration named a Commission on the Future of Higher Education. With many states now requiring education assessment at the university level (Durant 1997; Herring and Izard 1992; Jumper 1992), the balance has tipped toward agreement that assessment must become an essential part of contemporary college learning environments. The discussion centers on accountability for the public trust placed in the nation's institutions of higher learning; however, the stakeholders in higher education have also begun to focus on outcome assessment as the desired method for evaluating funded programs (Chonko and Cabarrelo 1991). To expect continued funding for programs, universities must have the ability to measure the value of learning. In addition, the Association to Advance Collegiate Schools of Business (AACSB), the premier accrediting body for American business schools, has revised its standards to require evidence of outcome assessment. This change was brought about, in part, as a result of the well-known Porter and McKibbin (1988) study of business school effectiveness, which revealed that while deans and administrators thought their schools were turning out good students, the employers of the students found them to be lacking in several critical competency areas. Political and governmental pressures, combined with new accreditation standards produce pressure on business schools to develop outcome measures and to ensure learning (Aguirre 1997).

The challenge for business schools, as well as for other college-level programs is to respond to these external pressures for change despite the many internal hurdles. Faculty, particularly have 
been shown to resist assessment for a variety of reasons (Barber et al. 2003). Perceptions are that assessment will increase faculty workloads and result in mountains of data that either cannot be used or that will be used against faculty members. Musun et al. (2006) note that the first step in developing a culture that allows the necessary changes is to create a climate of conversation.

Our experience shows that the conversation may begin more easily if it is focused on outcomes rather than assessment. A discussion about the outcomes students should display by the conclusion of a course or a program of study has an intuitive appeal that hooks faculty (Harden, Crosby, and Davis 1999; Borin, Metcalf, and Tietje 2007). Agreed-upon student learning outcomes drive course content, the selection of course materials, and pedagogy, as well as what is assessed (Harden et al. 1999; Borin et al. 2007). Because outcome-based education (OBE) is consistent with performance-based assessment, the conversation naturally flows from outcomes to assessment.

In a prior paper (Borin, Metcalf, and Tietje 2007), we delineated the approach we used to develop a marketing curriculum focused on achieving college-level, discipline-specific, and course-level learning outcomes. We described the process of curriculum development as zerobased because we began without reference to pre-existing courses, topics, or structures. We describe the resulting marketing curriculum as outcome-based, because it is built upon intended learning outcomes instead of topics. In the process of building a curriculum to achieve learning outcomes, we created courses that are distinctive to our college. For example, instead of a traditional consumer behavior course, we offer a course titled "Listening to the Customer" that enables students to uncover customer insights through secondary and qualitative marketing 
research. And, as noted above, in the process of developing an outcome-based curriculum, our conversations began to include assessment as well—how would we assess to what degree our students had achieved the learning outcomes we had identified?

In this paper, we explain the assessment plan we implemented to measure achievement of intended learning outcomes, and the process we used to develop the assessment plan. We demonstrate how developing an outcome-based marketing curriculum can lead a faculty to develop measures of context-specific learning, which in turn, opens a conversation on assessment. First, we review the literature on outcome-based education (OBE) and discuss the link between OBE and assessment. Second, we outline the six-step process we followed to develop and implement an assessment plan. Finally, we conclude by reflecting on our own assessment experience, as well as how it might offer a roadmap for others to follow in their own efforts to implement assessment programs and to begin the epic transition from a teaching to a learning organization.

Outcome-Based Education: A Natural Bridge to Assessment An outcome is defined as a successful demonstration of learning — what students are ultimately able to do—at the completion point of a segment of curriculum (Ewell 1988; Spady and Marshall 1991). Four key design elements characterize outcome-based education (OBE): focus on significant outcomes; design curriculum to achieve outcomes; set high expectations for achievement; and provide multiple opportunities to receive instruction and demonstrate learning (Spady and Marshall 1991). The first design element—focus on significant outcomes—is informed by descriptions of the future conditions that students are likely to encounter-a 
complex, challenging, and high-tech future. These future conditions serve as the starting point for outcome-based curriculum design and help guide the establishment of significant outcomes. To address the second design element, Spady and Marshall (1991) highlight the importance of setting existing curriculum aside when establishing future-driven exit outcomes. In other words, curriculum should be developed to support the outcomes students should demonstrate, as opposed to developing objectives for a curriculum that is already in place (Harden et al. 1999). The third design element—set high expectations for achievement—is predicated upon the notion that students must master outcomes, at a quality level that is at least thorough and complete, before they leave a program. The expectation is that all students demonstrate competence, which is different from conventional grading practices that accept and label all student performance, whether complete or not (Spady 1994). With respect to the fourth design element—providing more than one uniform, routine opportunity to receive instruction and to demonstrate successthe educator's role is twofold (Smith and Dollase 1999). The first is to create opportunities for students to practice content, concepts, and skills; to incorporate discoveries; and to practice again. The second is to guide, encourage, and facilitate student learning - the emphasis is on coaching rather than covering the curriculum, which shifts the focus to what students learn rather than what is being taught. Overall, the focus is on providing practice assignments and coaching students to master content, concepts, and skills before advancing them to material and courses that depend on those prerequisite learnings (Spady 1988).

OBE provides the foundation for strong assessment (Eastman, Allen, and Superville 2001). Because learning outcomes are specified in behaviorally measurable ways, there is a natural link between the intended learning outcomes of a program and the assessment of student achievement 
(Smith and Dollase 1999; Harden 2002). Over the past several years, a number of business schools have spent considerable effort developing statements of expected competencies for students (Palomba and Palomba 2001). The primary focus of outcomes assessment efforts should then be on the expected competencies reflected in these statements. Outcomes assessment addresses the question of whether or not the learning experienced in a program contributes to an improvement in the student. While many programs undertake formal assessment of student learning outcomes to satisfy accreditation standards, the ultimate goal of outcomes assessment is program improvement and increased student achievement (Walvoord 2004). Properly designed and executed, outcomes assessment should reveal the extent to which a program is contributing to the growth and development of its students. Outcomes assessment enables faculty to determine whether their programs are effective in producing graduates with the necessary knowledge, skills and values to function as valuable members of an organization and of society at large.

A number of studies outline the principles of effective assessment (c.f. Eastman et al. 2001; Huber, Heidenberg, Wilmer, and Phillips 2006; Nichols 1995; Ratcliff 1995). We used the framework established by Glassick, Huber and Maeroff (1997) and later presented by Eder (2004) to develop our assessment plan. Although there are a number of motivations for assessing a curriculum (Ratcliff 1995), our primary motivations were to improve student learning and to give direction to the improvement of our new marketing program. In the sections that follow, we will describe more fully the process we followed to develop an outcome-based marketing curriculum and an assessment plan, as well as our own experience along the way. 
Developing an Assessment Plan for an Outcome-Based Marketing Curriculum

The development of an outcome-based marketing curriculum has been presented previously (Borin, Metcalf, and Tietje 2007). Briefly, the new marketing curriculum was structured to achieve student learning outcomes, enabling students to build on what was learned in prior coursework (Terwell 2005) and giving students repeated exposure to problem-based issues that required increasingly sophisticated data analysis and reporting (Richard and Miller 1996; Wee, Kek, and Kelley 2003). As a faculty committed to problem-based learning, our discussions throughout the curriculum development process naturally gravitated toward what we wanted our students to be able to do after completing each of the six courses comprising our marketing curriculum instead of what they should know. An outcome-based orientation led us to seek more information on learning theory (c.f. Kolb 1983), learning objectives (c.f. Fink 2003; Gronlund 2004), outcome-based curricula (c.f. Harden et al. 1999; Smith and Dollase 1999), and assessment (c.f. AACSB’s Assessment / Assurance of Learning Seminar materials, http://www.aacsb.edu/resource_centers/assessment). We structured our assessment plan according to the framework found in Eder (2004). The framework and our application of it are presented in Table 1.

Insert Table 1 about here

1. Establish clear goals

2. Ensure adequate preparation 
3. Employ appropriate methods

4. Produce significant results

5. Arrange for effective presentation

6. Practice reflective critique

\section{Establish Clear Goals}

Goals represent what we want our students to be and typically serve as an overall directive for more detailed decisions. In developing the marketing program learning goal, we referred to three themes that had emerged from the marketing area's assessment of market trends and employer needs in regional industries: (1) firms were increasingly dependent on information and data analysis; (2) creativity and innovation were of universal importance within the marketing discipline; and (3) project-based courses involving actual clients produced graduates with distinctive strengths. Consequently, the marketing faculty agreed that each student completing the marketing program would be a competent data-driven decision maker with practical experience to implement innovative solutions to a variety of marketing challenges. A set of six courses, described previously in Borin et al. (2007) was proposed that would prepare students to become competent data-driven decision makers with practical experience to implement innovative solutions to a variety of marketing challenges.

\section{Ensure Adequate Preparation}

In contrast to the marketing program goal noted above, program-level and course-level learning objectives describe what we want our students to be able to do. Learning objectives define observable characteristics of student performance that can be captured by assignments. Learning 
objectives were established for each marketing course, as well as the marketing program overall, and the curriculum was developed with the achievement of learning objectives or outcomes in mind. Using verbs associated with the six cognitive levels (knowledge, comprehension, application, analysis, synthesis, and evaluation) in Bloom's (1984) taxonomy as a guide, outcome-based learning objectives were developed not only for each course but also for each class session.

Good learning objectives usually contain action verbs (Eder 2004), e.g., recall, apply, synthesize, evaluate. Learning objectives stated in this way indicate the level of performance expected and make achievement evident. Table 2 presents the six cognitive levels of Bloom's taxonomy with examples of course-specific learning objectives from some of the courses in our new curriculum. Learning objectives for a particular course were expressed to reflect several different cognitive domains. For example, important outcomes for the Strategic Marketing Measurement course were that students should not only understand (knowledge) different metrics but also be able to compute (analysis) them and solve problems or make decisions (application, synthesis) using them.

Insert Table 2 about here

Learning objectives, expressed at the program and course levels, would eventually drive the pedagogy and assessment within and across courses and were the most critical and timeconsuming part of the curriculum development process. The marketing faculty agreed that these learning objectives would remain consistent regardless of the faculty member teaching the 
course. Pedagogy and materials might vary, but the intended learning outcomes would not. Learning objectives for each of the six marketing courses mapped to marketing program-level learning objectives, which in turn could be mapped to college-level learning objectives as can be seen in Figure 1.

Insert Figure 1 about here

It is important to note that learning objectives for each course support only a subset of the eleven marketing program-level learning objectives; however, over the entire marketing curriculum, learning objectives for the marketing program are achieved. In turn, taken as a whole, the set of marketing program-level learning objectives support or map to all of the learning objectives for the college.

Employ Appropriate Methods.

There are many methods that can be employed to assess learning and there is widespread agreement that assessment methods should match the culture of an institution and entail multiple measures over time (Eder 2004). Generally, assessment methods can be categorized as either course-embedded or non-course embedded and direct or indirect methods. Course-embedded assessment relies on a review of materials (e.g. assignments, presentations, projects, exam questions, surveys, essays) generated by students as part of their regular coursework to determine whether or not student learning outcomes have been met. Direct measures require students to demonstrate a skill, quality, or value that is being measured (Hernon and Dugan 2004; Maki 
2004; Suskie 2004). Examples of direct measures include student performance on a specific course assignment, a senior project, or a specific test. Direct and course-embedded assessment methods are considered strong. Indirect measures suggest that students have achieved a given learning outcome, but do not require that students directly demonstrate that outcome (Hernon and Dugan 2004; Maki 2004; Suskie 2004). As an example, students might be asked whether they believe they have learned a certain skill, rather than having students actually demonstrate this skill. Other examples of indirect measures include faculty, employer, or student surveys about perceptions of learning; graduation or retention rate data; GPA; and graduate school or job placement rates. Indirect measures are best utilized in conjunction with direct measures (Hernon and Dugan 2004; Maki 2004; Suskie 2004). The marketing area’s curriculum was assessed using a combination of course-embedded, non-course embedded and direct and indirect methods. Direct, Course-Embedded Assessment. Driscoll's (1998) curriculum alignment grid was used as a means of ensuring that direct, embedded assessments were developed for each of the learning objectives expressed for each course. Driscoll suggests placing the learning objectives across the top of the grid, then placing each class day, along with course materials and learning activities along the side of the grid. We placed X's in the grid to indicate the points at which various learning objectives would be assessed by direct, course-embedded exercises, assignments, projects, or tests. For each learning unit in a given course, marketing faculty members created multiple learning experiences, in which students could practice skills, receive instructor feedback on their progress, incorporate discoveries, and demonstrate mastery. Students were expected to demonstrate proficiency on all learning objectives specified for a course. Course-embedded assessments of the learning objectives for each course were used in the normal computation of student grades. 
Student performance on assignments in all six marketing courses were assessed using rubrics that specify the primary traits students are expected to demonstrate and achievement levels for each of the primary traits. The principles of primary trait analysis can be found in Walvoord and Anderson (1998). As an example, an embedded exercise in the course Strategic Marketing Measurement was a written analysis of a case study that required students to calculate customer lifetime value. The grading rubric for this case is provided in Table 3.

Insert Table 3 about here

Indirect Assessment, Pre vs. Post-Program. In addition to the course-embedded assessments noted above, we administered three different non-course embedded assessments to students entering and exiting the marketing concentration (students in the Principles of Marketing and Marketing Strategy courses, respectively). The results did not factor into course grading and they allowed us to evaluate the changes in learning achieved by the curriculum (Ratcliff 1995; Eastman et al. 2001). First, a multiple-choice test was developed that represented the learning objectives for each course in the marketing curriculum. Second, a 92-item self assessment was developed to measure students' understanding of and confidence in their mastery of the unit objectives for each course. The survey also measured students' degree of satisfaction with the curriculum and the degree to which the program met their expectations. Survey items were measured on 7-point Likert scales: $1=$ don't understand at all to $7=$ understand completely; $1=$ not at all confident to $7=$ completely confident; $1=$ completely dissatisfied to $7=$ completely satisfied; 1 = did not meet my expectations to 7 = exceeded my expectations; 1 = strongly 
disagree to 7 = strongly agree. Third, a short case analysis was developed that mapped to courselevel learning objectives. These included segmentation, targeting and positioning and data analysis. A rubric was developed for assessing student mastery of key elements of the case. A detailed set of instructions was presented to the instructor on how to implement the tools.

\section{Produce Significant Results}

The primary question here is whether or not a curriculum produces students who are able to successfully demonstrate learning on key objectives (Eder 2004; Spady \& Marshall 1991). As can be seen by the sample rubric presented in Table 3, the marketing faculty set rigorous performance standards and all students in the marketing program are expected to accomplish course-level learning objectives at high performance levels.

Direct, Course-Embedded Assessments. Table 4 provides representative results for embedded assessment across several courses in our curriculum.

Insert Table 4 about here

Initial results are encouraging. A relatively low percentage of student work (7.9\%) was classified as unacceptable, and almost a third (28\%) was classified as superior. There was, however, some variability in student performance on certain objectives, meriting attention for curricular or pedagogical enhancements. Furthermore, the relatively high scores in certain courses raised our concern that some professors were applying different standards than others when using the rubrics. We address this calibration and consistence issue in the reflective critique section of this paper. 
Indirect Assessment, Pre vs. Post-Program. Marketing faculty members were interested in determining whether students completing the program could demonstrate achievement on the learning objectives significantly better than those entering the curriculum. On all items of the self-assessment, students in the capstone marketing course rated their understanding and ability of key marketing concepts significantly higher than those entering the curriculum ( $\mathrm{p}=.000)$. Means for students in the capstone Marketing Strategy course were generally around 5.0, while means for the Principles of Marketing students ranged from 2.0-2.5. These results were consistent with expectations since this is an indirect self-assessment. Means for both groups on the multiple choice exam were low, with averages below 65\%. However, the average for the Marketing Strategy students was significantly higher than those of the students in the Principles of Marketing class $(\mathrm{p}=.000)$. Similar results were found for the short case analysis used to measure key program-level learning objectives. Students exiting the marketing program through the capstone Marketing Strategy course performed significantly better than the entry level students ( $\mathrm{p}=.013)$. These direct assessment results were encouraging and reflected our belief that the curriculum was accomplishing its objectives. Table 5 provides summary results for the nonembedded analysis.

Insert Table 5 about here

Arrange for Effective Presentation 
As the second year of our new curriculum draws to a close, all faculty teaching the six courses in the marketing curriculum have now introduced course-embedded assessment methods and are using rubrics to evaluate student mastery and to provide feedback. We are currently in the process of working with adjunct instructors to help them introduce direct, course-embedded assessments and rubrics that identify primary traits and establish performance levels into the Principles of Marketing class.

\section{Practice Reflective Critique}

The most critical component of the assessment process is using the results to evaluate and modify the curriculum if necessary. How will we connect assessment reports to curriculum improvement? After two years of experience with the new marketing curriculum, the marketing faculty has had an opportunity to discuss and to modify many aspects of the curriculum and the assessment process. These modifications have taken into account faculty experience, as well as feedback from students, alum and other stakeholders. They are enumerated below.

1. Auxiliary learning support, such as a marketing information competency Web site, has been developed and improved over time. The marketing information competency Web site allows students to practice and review difficult aspects of the curriculum. In another example, Web-based statistics modules eliminate the necessity to review basic statistics and allow faculty members to focus more attention on the key learning objectives of the qualitative and quantitative data analysis courses.

2. We learned very early in the process that the timing of assessment data collection in a course significantly impacts the measures. Assessment results captured when students were first introduced to a concept or skill were not measuring mastery, which is the goal 
of assessment. Therefore, we adjusted the timing of assessment data collection to occur near the end of the term when students have presumably reached a mastery level of achievement. Scores that are captured earlier in the quarter provide students with preliminary feedback on their learning, but are not reported for assessment purposes.

3. Faculty meet as a group during the summer and review results from each of the courses. These results are used in conjunction with input from the undergraduate program committee to address issues in the curriculum. For example, it was determined that the marketing area's course objectives did not adequately address the college’s learning objectives related to business ethics. The area used this information to add an additional ethical component to its introductory marketing course.

4. Faculty members distribute rubrics such as the one presented in Table 3 to students at the start of the quarter, identifying the primary traits that will be assessed for each learning exercise or activity. Clearly communicating the standards against which their work will be judged encourages students to take more responsibility for the quality of the work they turn in. It emphasizes accountability and enables them to gauge their own performance. Feedback from students has generally been positive, but some students have found the use of rubrics unconventional and have asked for additional feedback. Professors have responded by adding additional detail to each of the rubric levels.

5. Faculty members have discovered that the use of rubrics and primary trait analysis has facilitated grading. Rather than writing explanations on assignments and reports, faculty members simply return the rubrics with the level of achievement indicated for each trait.

6. The marketing area has eliminated all non-imbedded assessment tools at the current time. Both faculty and students found little motivation to seriously focus on assessment tools 
that did not directly impact course grades. However, we are currently evaluating the possibility of assessing the long term retention of key learning outcomes using alumni surveys.

7. Assessment results indicating student performance on learning objectives have greatly assisted faculty members in making course modifications. All changes-new course materials, adjustments in course calendars, additional learning exercises or changes to existing exercises - are always evaluated based on the ability to help students achieve learning objectives.

8. In retrospect, we were overly optimistic about our ability to measure a vast quantity of learning objectives. The college had six program-level learning objectives, the marketing area faculty had eleven for the marketing program level, and each course had 20-30 learning objectives, of which 2-3 were identified as key learning objectives. The number of learning objectives far exceeded our ability to either develop pedagogies to help students learn them or to measure students’ mastery of them. We have since stepped back and reduced the number per class session and the overall number per class. We have also developed a mapping between the area's key learning objectives and the college’s learning objectives, rather than trying to measure the college’s learning objectives separately.

9. In the process of recruiting new faculty to our area, we have received positive feedback about our assessment program. Candidates from institutions that are undertaking AACSB accreditation or reaccreditation have only recently been exposed to the concept of outcome based learning. They are excited about the potential of working at an institution 
that has moved forward with this process and are very receptive to having the objectives and rubrics already prepared for their courses.

10. Students appreciate the focus of the new curriculum and the integration among courses, which gives them repeated exposure to problem-based issues that require increasingly sophisticated analysis and which enables them to build skills over the entire set of courses.

11. We learned firsthand that assessment is an activity that must be accomplished by the faculty as a collective whole. Assessment is not an individual activity. For example, our initial use of embedded assessment relied on instructors to apply rubrics in their courses. After viewing the direct-embedded assessment results, we realized that calibration is necessary so that faculty members understand how to apply the same standards to student work.

Conclusion

Combined with an earlier piece (Borin et al. 2007) this paper provides a roadmap for faculty considering developing and assessing an outcomes based curriculum. Implementing an outcome-based marketing curriculum and developing measures of context-specific learning ahead of other areas in the College, positioned us well to lead the College in implementing measures of assessment that make sense in our context. Our work has facilitated the College's efforts to align itself with AACSB standards for student learning outcomes assessment and for continuous program improvement. Additionally, we hope that the approach outlined above and our experience with it may provide a useful roadmap to other marketing faculties interested in developing an outcome-based curriculum and an assessment plan that leads to continuous program improvement. 
Figure 1

The Hierarchy of Learning Goals and Objectives in Curriculum and Course Development With Illustrative Examples

\section{College Learning Goals}

College program goal \#4: Students will be creative data-driven decision makers.

\section{College Learning Objectives}

College program objective \#4: Students will analyze and evaluate alternative solutions to problems, using appropriate data to support decisions.

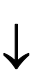

\section{Discipline-Specific Learning Goals}

Marketing program goal: Each student completing the marketing program will be a competent data-driven decision maker with practical experience to implement innovative solutions to a variety of marketing challenges.

\section{Discipline-Specific Learning Objectives}

Marketing program objective \#2: Select appropriate tools and techniques to seek, analyze, \& interpret data.

Course Learning Objectives

(From Strategic Marketing Measurement) Analyze descriptive and statistical survey data to draw conclusions, formulate and communicate strategic recommendations. 


\section{Class Session Objectives}

(From a class session using SPSS to analyze survey data.) Synthesize statistical results into interpretable findings. 
Table 1

Six Step Process for Developing and Implementing the Assessment Plan

Adapted from Eder (2004)

\begin{tabular}{|c|c|c|}
\hline Step & Comments & Our Application of this Step \\
\hline $\begin{array}{l}\text { 1. Establish clear } \\
\text { goals }\end{array}$ & $\begin{array}{l}\text { Learning goals describe what you } \\
\text { want your students to be or have. }\end{array}$ & $\begin{array}{l}\text { Competent data-driven decision } \\
\text { makers with practical experience to } \\
\text { implement innovative solutions to a } \\
\text { variety of marketing challenges. }\end{array}$ \\
\hline $\begin{array}{l}\text { 2. Ensure adequate } \\
\text { preparation. }\end{array}$ & $\begin{array}{l}\text { Learning objectives describe } \\
\text { what students should do or make. }\end{array}$ & $\begin{array}{l}\text { Learning objectives were } \\
\text { developed for each level of } \\
\text { programmatic implementation: } \\
\text { College (Business), discipline } \\
\text { (Marketing), course, and individual } \\
\text { class session. }\end{array}$ \\
\hline $\begin{array}{l}\text { 3. Employ } \\
\text { appropriate methods }\end{array}$ & $\begin{array}{l}\text { Options include direct, indirect, } \\
\text { and embedded assessment. }\end{array}$ & $\begin{array}{l}\text { We used three methods: } \\
\text { - Direct embedded measures using } \\
\text { rubrics and individual course } \\
\text { assignments. } \\
\text { - Direct measures of performance } \\
\text { using a multiple-choice exam and } \\
\text { case study analysis comparing } \\
\text { students entering and exiting the } \\
\text { curriculum. }\end{array}$ \\
\hline
\end{tabular}




\begin{tabular}{|c|c|c|}
\hline & & $\begin{array}{l}\text { - Indirect measure of students' } \\
\text { understanding of and confidence in } \\
\text { their mastery of the unit objectives } \\
\text { for each course using a 92-item } \\
\text { self-assessment quiz. }\end{array}$ \\
\hline $\begin{array}{l}\text { 4. Produce } \\
\text { significant results }\end{array}$ & $\begin{array}{l}\text { Ask the question - do the results } \\
\text { suggest a need to make changes } \\
\text { to our curriculum or pedagogy? }\end{array}$ & $\begin{array}{l}\text { Our first year results showed: } \\
\text { - A relatively high percentage of } \\
\text { students achieved acceptable levels } \\
\text { of student learning across courses } \\
\text { and learning objectives, but the } \\
\text { percentage of students not } \\
\text { achieving acceptable levels } \\
\text { warrants careful consideration. } \\
\text { - Students completing the program } \\
\text { demonstrated achievement on the } \\
\text { learning objectives significantly } \\
\text { better than those entering the } \\
\text { curriculum, as measured by the } \\
\text { self-assessment, multiple choice } \\
\text { exam and case study analysis. }\end{array}$ \\
\hline $\begin{array}{l}\text { 5. Effective } \\
\text { presentation }\end{array}$ & $\begin{array}{l}\text { Results are summarized, } \\
\text { disseminated, and reviewed. }\end{array}$ & $\begin{array}{l}\text { The marketing department } \\
\text { reviewed the results and discussed } \\
\text { potential modifications to the }\end{array}$ \\
\hline
\end{tabular}




\begin{tabular}{|l|l|l|}
\hline & & $\begin{array}{l}\text { curriculum and pedagogy to } \\
\text { enhance student learning. }\end{array}$ \\
\hline 6. Practice reflective & "Closing the loop” between the & Because results were only from one \\
critique & $\begin{array}{l}\text { results and curricular or } \\
\text { pedagogical improvement. }\end{array}$ & $\begin{array}{l}\text { year, relatively minor changes were } \\
\text { made for now. }\end{array}$ \\
\hline
\end{tabular}


Table 2

Using Bloom’s Taxonomy to Develop Learning Objectives

\begin{tabular}{|c|c|}
\hline Cognitive Domain & Representative Course-Level Learning Objectives (Course Title) \\
\hline Knowledge & $\begin{array}{l}\text { Define nominal, ordinal, interval, and ratio data. (Strategic Marketing } \\
\text { Measurement) } \\
\text { Memorize the characteristics of an innovation that impact the rate of } \\
\text { adoption, e.g. trial, observability, affordability, relative advantage, and } \\
\text { complexity. (New Product Development and Launch) }\end{array}$ \\
\hline Understanding & $\begin{array}{l}\text { Discuss alternative approaches to calculating customer lifetime value. } \\
\text { (Strategic Marketing Measurement) } \\
\text { Recognize the types of situations where observation or mystery shopping } \\
\text { techniques are effective. (Listening to the Customer) }\end{array}$ \\
\hline Application & $\begin{array}{l}\text { Calculate key marketing metrics. (Strategic Marketing Measurement) } \\
\text { Calculate chi-square, t-test, ANOVA for different profit groups. } \\
\text { (Strategic Marketing Measurement) }\end{array}$ \\
\hline Analysis & $\begin{array}{l}\text { Compare and contrast nontraditional and traditional promotional tools. } \\
\text { (Product Management) } \\
\text { Differentiate between the operational and conceptual aspects of customer } \\
\text { profitability. (Strategic Marketing Measurement) }\end{array}$ \\
\hline Synthesis & $\begin{array}{l}\text { Plan a search strategy for locating relevant and insightful secondary } \\
\text { research. (Listening to the Customer) }\end{array}$ \\
\hline
\end{tabular}




\begin{tabular}{|l|l|}
\hline & $\begin{array}{l}\text { Formulate follow-on questions during an interview to correct, clarify, \& } \\
\text { amplify responses. (Listening to the Customer) }\end{array}$ \\
\hline Evaluation & $\begin{array}{l}\text { Compare \& contrast how best-in-class companies manage for } \\
\text { innovation. (New Product Development \& Launch) } \\
\text { Select and defend appropriate pricing strategy and tactics. (Product } \\
\text { Management) }\end{array}$ \\
\hline
\end{tabular}


Table 3

Sample Grading Rubric for a Case Study in Strategic Marketing Measurement

\begin{tabular}{|c|c|c|c|}
\hline Criterion & Poor & Acceptable & Excellent \\
\hline $\begin{array}{l}\text { Professionalism and } \\
\text { accuracy of grammar, } \\
\text { spelling, writing } \\
\text { style, and formatting. }\end{array}$ & $\begin{array}{l}\text { Numerous errors, } \\
\text { unprofessional } \\
\text { formatting, confusing } \\
\text { and unstructured } \\
\text { content. }\end{array}$ & $\begin{array}{l}\text { Few errors, direct and } \\
\text { concise writing } \\
\text { style. } \\
\text { Questionable choices } \\
\text { for narrative text } \\
\text { and visual data } \\
\text { formatting (e.g., } \\
\text { overuse or misuse } \\
\text { of bullets, no visual } \\
\text { data) }\end{array}$ & $\begin{array}{l}\text { No errors, direct and } \\
\text { concise writing } \\
\text { style. } \\
\text { Professionally } \\
\text { formatted with text } \\
\text { and visual data. }\end{array}$ \\
\hline $\begin{array}{l}\text { Quality of } \\
\text { recommendations }\end{array}$ & $\begin{array}{l}\text { Recommendations do } \\
\text { not clearly indicate } \\
\text { a decision. } \\
\text { Recommendations } \\
\text { are neither } \\
\text { actionable nor } \\
\text { realistic. } \\
\text { Recommendations }\end{array}$ & $\begin{array}{l}\text { Recommendations } \\
\text { clearly indicate a } \\
\text { decision. } \\
\text { Recommendations } \\
\text { are actionable and } \\
\text { realistic. } \\
\text { Recommendations } \\
\text { are not clearly }\end{array}$ & $\begin{array}{l}\text { Recommendations } \\
\text { clearly indicate a } \\
\text { decision. } \\
\text { Recommendations } \\
\text { are actionable and } \\
\text { realistic. } \\
\text { Recommendations } \\
\text { are clearly }\end{array}$ \\
\hline
\end{tabular}




\begin{tabular}{|l|l|l|l|}
\hline & $\begin{array}{l}\text { are not supported } \\
\text { by analysis. }\end{array}$ & $\begin{array}{l}\text { supported by } \\
\text { analysis. }\end{array}$ & $\begin{array}{l}\text { supported by } \\
\text { analysis. }\end{array}$ \\
\hline
\end{tabular}




\section{Table 4}

Sample of Embedded Assessment Results

\section{Learning Objective}

Course or Trait Evaluated Unacceptable Acceptable Superior

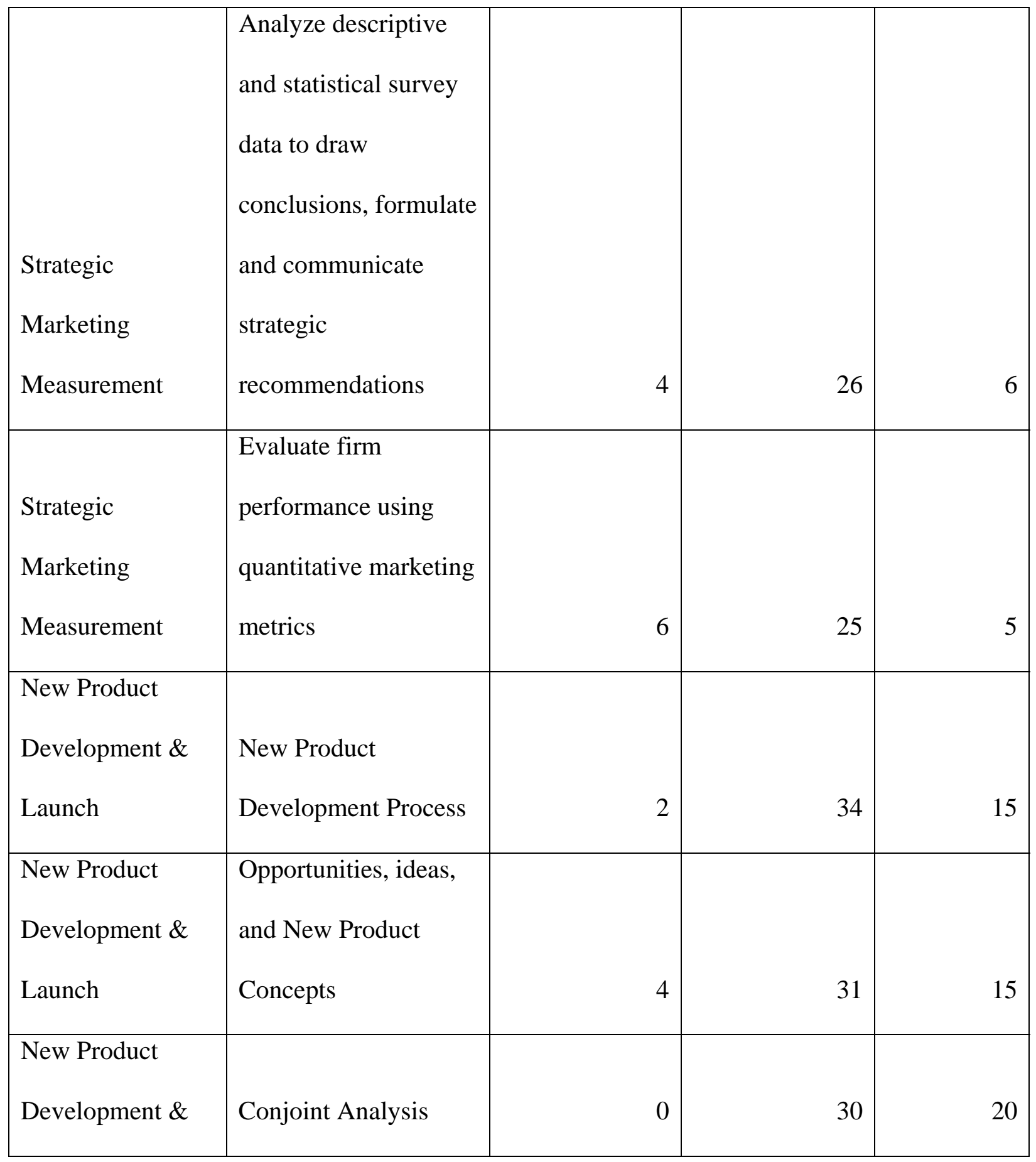




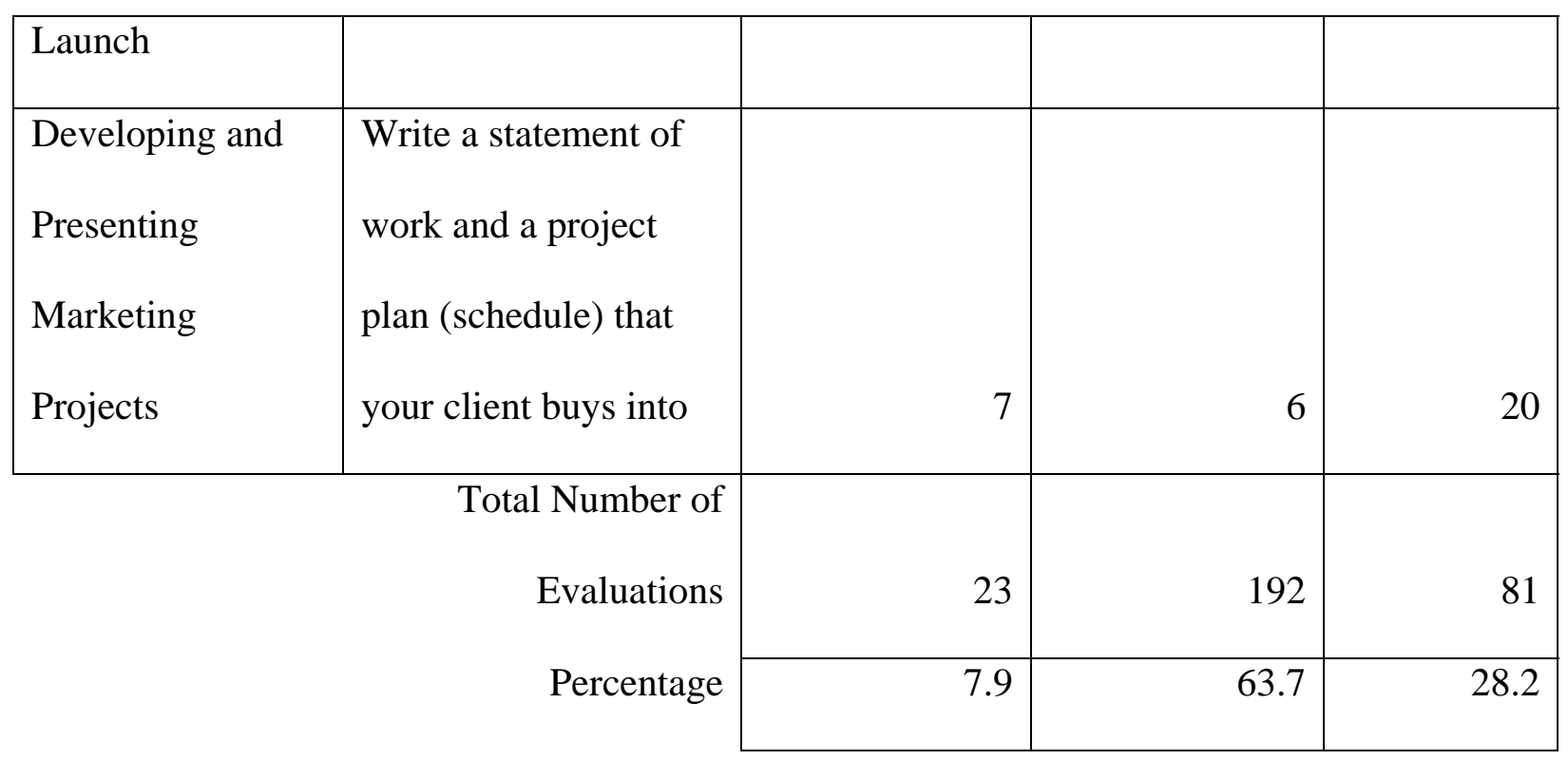


Table 5

Non-Embedded Assessment Results

\begin{tabular}{|l|c|c|c|}
\hline & $\begin{array}{c}\text { Entering Students } \\
\text { Mean Score }\end{array}$ & $\begin{array}{c}\text { Graduating Students } \\
\text { Mean Score }\end{array}$ & p-value \\
\hline $\begin{array}{l}\text { Case Score } \\
\text { (out of 16 points) }\end{array}$ & 9.5 & 10.9 & .013 \\
\hline Multiple Choice & 51 & 64 & .000 \\
(percent correct) & & & .000 \\
\hline Self Assessment (Mean on & 2.41 & 5.36 & .000 \\
\hline Knowledge Variables & 1.92 & 5.03 & \\
Ability Variables & & & \\
\hline
\end{tabular}




\section{References}

Aguirre, M., Mayes B. T., \& Belloli, C. (1997). Assessment centers: Innovative applications in higher education for the $21^{\text {st }}$ century. unpublished article. www.sbaer.uca.edu/Research/1997/WDSI/97wds390.txt

Banta, T. W. (2006). Reliving the history of large-scale assessment in higher education. Assessment Update, 18(4), 3-4.

Bloom, B. S. (1984). Taxonomy of educational objectives. Boston, MA: Allyn and Bacon.

Borin, N., Metcalf, L.E., \& Tietje, B. (2007). A replicable, zero-based model for marketing curriculum innovation, Journal of Marketing Education, 20(10), 1-11

Boyatzis, R.E., Cowen, S.S., \& Kolb, D.A. (1992). Implementing curricular innovation in higher education: Year one of the new Weatherhead MBA program, Selections, 9 (Autumn), 19.

Chonko, L.B. \& Cabellero, M.J. (1991). Marketing madness, or how marketing departments think they're in two places at once when they're not anywhere at all (according to some), Journal of Marketing Education, 13 (Summer), 14-25. 
Cook, C. W. (1993). Curriculum change: Bold thrusts or timid extensions. Journal of Organizational Change Management, 6(1), 28-40.

Dobni, D., \& Dobni, B. (1996). Canadian business schools: Going out of business? Journal of Education for Business, 72(1), 28-36.

Driscoll, A. (1988). Course alignment grid. California State University, Monterrey Bay: Center for Teaching, Learning, and Assessment.

Durant, R.F. (1997). Seizing the moment: Outcomes assessment, curriculum reform, and MPA education, International Journal of Public Administration, 20 (February), 397-429.

Eastman, J.K., Allen, R.C., \& Superville, C.R. (2001). Developing an MBA assessment program: Guidance from the literature and one program's experience._B-Quest, http://www.westga.edu/ bquest/2001.

Eder, D. J. (2004). General education assessment within the disciplines. The Journal of General Education, 53(2) 135-157.

Erwin, T. D., (1991) Assessing Student Learning and Development. San Francisco, Ca. JosseyBass. 
Ewell, P. T., (1988) Outcomes, assessment, and academic improvement: in search of usable knowledge. In Smart, J. C., ed. Higher education handbook of theory and research. New York: Agathon Press Inc. pp.53-108

Fink, D. L. (2003). Creating significant learning experiences. San Francisco: Jossey-Bass.

Glassick, C.E., Huber, M.T., \& Maeroff, G.I. (1997). Scholarship Assessed. San Francisco: Jossey-Bass.

Gronlund, N. E. (2004). Writing instructional objectives for teaching and assessment. Upper Saddle River, NJ: Pearson.

Guskin, A.E. (1996). Facing the future: The change process in restructuring universities. Change, 7-37.

Harden, R. M. (2002). Developments in outcome-based education. Medical Teacher, 24(2), 117120.

Harden, R. M., Crosby, J. R., \& Davis, M. H. (1999). AMEE guide no. 14: Outcome based teaching: Part 1 - an introduction to outcome-based teaching. Medical Teacher, 21(1), 714. 
Hernon, P. \& Dugan, R.E. (Eds.). (2004). Outcomes assessment in higher education: Views and perspectives. Westport, CT: Libraries Unlimited.

Herring, H. C. III and Izard, C. D. (1992). Outcomes assessment of accounting majors. Issues in Accounting Education, 7 (Spring), 1-17.

Jumper, S. (1992). Program assessment in geography: Boondoggle or opportunity, Journal of Geography 91(May-June), 94-96.

Kolb, D. A. (1983). Experiential learning: Experience as the source of learning and development. Englewood Cliffs, NJ: Prentice-Hall.

Maki, P. L. (2004). Assessing for learning: Building a sustainable commitment across the institution. Sterling, VA: Stylus Publishing, LLC.

Musun, L., Baker, A.D., \& Fulmer, J. (2006). Creating a campus community for conversation about assessing student learning. Assessment Update, 18(4), 1.

Nichols, J.O. (1995). A practitioner's guide for institutional effectiveness and student outcomes assessment implementation. New York: Agathon Press.

Palomba, C. \& Banta, T. (1999) Assessment essentials, planning, implementing, and improving assessment in higher education. San Francisco: Jossey-Bass. 
Palomba, N. and Palomba, C. (2001). Assessment of student competence in business, In C. Palomba and T. Banta (Eds.), Assessing student competence in accredited disciplines, Sterling, VA: Stylus Publishing. 121-139.

Parry, L. E., Rutherford, L., \& Merrier, P. A. (1996). Too little, too late: Are business schools falling behind the times? Journal of Education for Business, 293-299.

Paulsen, Michael B. and Bruce A. Peseau (1992) A practical guide to zero-based curriculum review. Innovation of Higher Education, 16(3), 211-221.

Porter, L.W., \& McKibbin, L.E. (1998). Management education and development: Drift or thrust into the $21^{\text {st }}$ century. New York: McGraw Hill.

Ratcliff, J. (1995). Turning results into improvement strategies. University Park, PA: Penn State University, NCTLA.

Richard, T. L., \& Miller, J. S. (1996). Re-forming the sociology major: A program to enhance the teaching of sociology at the undergraduate level. The International Journal of Sociology and Social Policy, 16(11), 32-64.

Sergiovanni, T. M. (1998). Organization, market, and community as strategies for change: What works best for deep changes in schools. In A. Hargreaves, A. Lieberman, M. Fullan \& D. 
Hopkins (Eds.), International handbook of educational change. Dordrecht: Kluwer Academic Publishers.

Smith, S. R., \& Dollase, R. (1999). AMEE guide no. 14: Outcome-based education: Part 2 planning, implementing, and evaluating a competency-based curriculum. Medical Teacher, 21(1), 15-22.

Spady, W.G. (1988). Organizing for results: The basis of authentic restructuring and reform. Educational Leadership, 46(2), 4-8.

Spady, W.G. (1994). Choosing outcomes of significance. Educational Leadership, 51(6), 18-22.

Spady, W.G. \& Marshall, K.J. (1991). Beyond traditional outcome-based education. Educational Leadership, 49(2), 67-72.

Suskie, L. (2004). Assessing student learning: A common sense guide. Bolton, MA: Anker Publishing Company, Inc.

Terwel, J. (2005). Curriculum differentiation: Multiple perspectives and developments in education. Journal of Curriculum Studies, 37(6), 653-670.

Torgerson, R.L. (1991). Assessing student academic achievement: Bethany College, North Association Quarterly, 66(Fall), 477-481. 
Walvoord, B. E. (2004). Assessment clear and simple: A practical guide for institutions, departments, and general education. San Francisco, CA: Jossey-Bass.

Walvoord, B. E. \& Anderson, V.J. (1998). Effective grading: A tool for learning and assessment. San Francisco, CA: Jossey-Bass.

Wee, L., Kek, M., and Kelley, C. (2003), Transforming the Marketing Curriculum Using Problem-Based Learning: A Case Study. Journal of Marketing Education, 25(2), 150162. 